\title{
GOVERNMENT EXPENDITURE, POLITICAL CYCLE \& RENT-SEEKING
}

\author{
Taufiq Arifin* \\ Universitas Sebelas Maret \\ Nasyiah Hasanah Purnomowati \\ Universitas Sebelas Maret
}

\begin{abstract}
Decentralization and direct election have prospective to improve and expand the prosperity of the society and also enhance accountability of the government. On the other hand, competition in the election might create incentive for incumbent to abuse their power to misallocate of the regional budget. This study aims to examine the pattern of regional budget around the election years. Using Indonesian municipals in democratized period as a sample, we find that in the budget allocation for social expenditure and grant expenditure are more likely to increase two years prior to the election year. These increase become higher close to election year. If the incumbent running for re-election, these expenditures are more likely to increase. We find a weak evidence of political budget cycle among the incumbent during the election year.
\end{abstract}

Keywords: Political Budget Cycles; Rent-Seeking; Government Expenditure.

\section{INTRODUCTION}

Prior studies show that political budget cycle (PBC) occurs in new democratic countries (Brender, 2003; Brender and Drazen, 2005; Shi and Svensson, 2006). The fall of President Soeharto, second president who ruled for 32 years, marked a crucial turning point for Indonesia's democracy. The 1999 election was the first genuinely democratic election since 1955. In 2005, Indonesia became a presidential democracy. Indonesian citizen vote directly the president, regional governor, national and regional representative council (DPR/DPRD). These democratic reform result in more transparent and accountable election process for Indonesian. However, this direct election might lead to greater political competition and high-cost democracy. Winning the elections becomes the ultimate goal of every party and candidate at all costs. High cost in political campaign leave room for expropriation. Political corruption and money politics became more severe. Valsecchi (2013) find that direct elections increase the number of corruption crimes in Indonesia. Consistently, Sjahrir et al., (2013) find that incumbents expropriate local government budget through discretionary funds to increase the probability of reelection. This PBC phenomenon becomes more prevalent in period of direct regional elections.

Since decentralization distribute power to local politicians, regional elections would seem to provide an abundant corruption practice, money politics, and nepotism between candidates and voters. Many voters expect 'appreciation' for the votes they have or may cast, not only in cash also in donation and provision during the period of election (Simandjuntak, 2012). This corruption behavior tends to expropriate APBD

\footnotetext{
- Corresponding author: Faculty of Economics and Business, Universitas Sebelas Maret. email: taufiqar@staff.uns.ac.id
} 
(Regional Governments Budget) for personal benefit. Based on data from KPK (Corruption Eradication Commission), from 332 corruption suspects during 2004-2011, most of the suspects are the 1st and 2nd grade of government upper-echelon officials with 106 suspects, 69 suspects of private party, 65 suspects of parliament member, and another 31 suspects are the district heads and provincial governors.

Asymmetries information and weak governance may lead to expropriation of the executive by allocate resources inefficiently. Mauro (1998) found that most of the budgets will be likely allocated to projects that are easy to be corrupted or popular project rather than for social and economies benefit. These expropriation are more severe during electoral period, particularly if the incumbents re-electable because political budget cycle is driven by re-election incentives. The incumbents have incentives to execute programs that are popular rather than beneficial. Generally, PBC results in reducing other budget allocation such as health-care, education, and another essential public spending. Misallocation of government budget will significantly influence the regional economic growth. PBC might be a preliminary red flag of rent-seeking behavior or even a corruption. Empirical investigation of PBC will provide evidence whether this behavior are prevalent across region in Indonesia.

This research extend previous studies on political budget cycle (PBC) phenomena in Indonesia by examining disaggregation of government expenditure that might indicate a rent-seeking behavior. Sjahrir et al. (2013) are the first to explore the political budget cycle in Indonesia. However, their focus on their paper in on discretionary and non-discretionary expenditures. Moreover, they find that the discretionary expenditure shows a cyclical pattern in direct election and especially if the incumbent running for reelection.

In order to examine the political budget cycle specifically in direct election period, we exploit the particular discretionary expenditure in district level across different period of elections. Instead of using fiscal policy (e.g. total government spending, expenditures in development projects, administrative expenditures) to capture political budget cycle, this research uses particular expenditures budget that are more prone to abuse such as social grant expenditure and grant expenditure. In particular, we measure the expropriation at district level by using audit report of National Audit Bureau (BPK) on social grant expenditure and grant expenditure. Our dataset provide advantages to investigate the relationship between PBC and rent seeking behavior. These proxy provide more reliable measurement of rent seeking behavior which is usually difficult to capture. This proxy cover almost all region in district level.

The results from this study provide evidence that rent-seeking behavior arise not only on the election year but also 2 years prior to election. These rent-seeking behavior become higher in the election year. We find a weak evidence of rent-seeking behavior by incumbent in the election year.

The reminder of this study is organized as follows. Section 2 contains the literature review from which the hypotheses are developed. Section 3 discusses the research methodology, followed by discussion of the results. Section 4 contains the conclusion summarize the main findings of the paper and includes a discussion on identified limitations and future research directions.

\section{LITERATURE REVIEW AND HYPOTHESES DEVELOPMENT}

Economic and political literature provide ample evidence to explain the relationship between business and government through two important theories: the rent-seeking theory (Krueger, 1974) and the grabbing hand theory (Shleifer and Vishny, 1994, 1998). These two theories explain how political 
figures (politicians and bureaucrats) take benefit from their position and power only for their group or personal benefits. Rent-seeking theory explains that bureaucrats and politicians tend to abuse their position and power for the benefit of their affiliated parties (take bribery case for instance). The grabbing hand theory explains that there are phenomena of state assets exploitation for the benefit of incumbent bureaucrats and politicians. Rent-seeking practice in Indonesia is exacerbated by the regional's weak administrative governance (Arifin et al., 2015).

Furthermore, the rent-seeking and corruption behavior can be specifically explain from the perspective of the agents in the process of regional governments organization, by observing society relations, regional executives/governments, and regional representative council (DPRD). The executive can act as an agent in its relation with the legislative. Legislative can also play a role as an agent in its relation with the society/people as voters. The agency problem will likely arise if each party in principal-agent relation put their own interests above others. According to Becker and Stigler (1974), scholars and researchers identify corruption as a part of principal-agent relation (e.g., Banfield, 1975; RoseAckerman, 1975, 1978; and Klitgaard 1988).

Better and proper allocation of government resources will significantly boost economic growth. The proper allocation for public expenditure will also overcome market failure and problems related with poverty, such as inability to access the education, health, or other basic needs. However, to some extent, the raging corruption practices in Indonesia indicate the failure of government's role in distributing the wealth and resources to public fairly.

APBD (regional government budget) is an important instrument in administration of a regional government. These instrument serves as the embodiment of regional government policy regarding how the regional resources are obtained and used. The APBD reflects government's policies in resource allocation to enhance economic growth and provide public services such as education, health, transportation social security, and job opportunities.

The executive and legislative, who has almost the absolute power, tends to abuse his/her power and influence to exploit the resources allocation for his/her group and personal interests. This condition is exacerbated when the legislative as a supervisory mechanism and control function toward the executive becomes part of rent-seeking practice.

In democratized and decentralized era, arrangement of APBD is a political process. The APBD drafting process involves various parties, not only officials who are directly elected by the people through the elections, but also the bureaucrats and other non-formal parties outside the government system and formal political institution. The more parties involved in the drafting, from planning to ratification, the bigger the conflict of interest will be. This conflict of interest is prone to manipulation and regional budget abuse.

Social assistance and grant expenditures are vulnerable to manipulation due to their characteristic as a discretionary expenditure which does not have a clear form program. They often become instruments to lure the voters (Farhan, 2013). Based on the data from ICW (Indonesian Corruption Watch), there are 120 cases of social assistance fraud during 2007-2012. Approximately, 300 trillion rupiahs are used to fund the incumbents' campaign instead of grants and social assistance. The grants and social assistance budget are often not properly spent based on existing regulation and does not meet the needs of the people. 
Government budget corruption is caused by several factors, such as the low-possibility to be detected, weak law enforcement and lack of monitoring, low salary and compensation, and lack of moral and ethical standards of the government officials. Prominent politicians and bureaucrats will select a project not because of its priority, but for personal benefit (Martinez-Vazquez, 2006).

Other empirical researchers also show the similar evidence. Tanzi and Davoodi (1997) show another empirical evidence about the existence of opportunistic politicians behavior dealing with public investment. The reason why politicians prefer making decisions related to (1) the magnitude of public investment budget, (2) the composition of public investment budget, (3) the selection of special project and allocation, and (4) the quantity of every public investment project because those decisions could potentially misallocate for personal preferences. For example, they will give government project tenders to those who is willing to give them commission.

Prior literature in political budget cycle have been widely conducted in Indonesia (Mietzner, 2011; Simandjuntak, 2012; Sjahrir et al., 2013). Direct elections in regional government in Indonesia now are more likely to create incentives to corrupt, bribe, and nepotism between the candidates and the voters (Mietzner, 2011). As a form of compensation for the votes that they have or may cast, voters usually expect some money that is usually distributed minutes before the elections begin. Voters also strongly expects for donation and the provision during the period before the election (Simandjuntak, 2012). Sjahrir et al. (2013) found that PBC phenomenon in Indonesia only occurs during the period of direct elections. The pattern of PBC did not occur during the period of indirect election (before 2005). The phenomenon of $\mathrm{PBC}$ is more rampant when the incumbents rerun for the next elections.

The legislative tendency to allocate projects that contains lucrative opportunities encourage them to urge the executive to raise the allocation in some sectors that support their interest or that will bring benefits in the long run. As a result, legislative tend to propose a reduction over the allocation for education, health, and other public spending because they are job programs and targetable. This legislative preference has 3 possible impacts on the allocation to other sectors, namely: (1) reducing the allocation for other expenditures if the amount of overall expenditure is not increasing; (2) not changing the allocation of other sectors expenditure if the amount of overall expenditure are increasing; or (3) both combination, reducing the allocation of other sector expenditure although the number of overall expenditures is increasing (Abdullah and Asmara, 2006).

This research investigate the PBC phenomenon in decentralized Indonesia. PBC phenomenon might indicate the existence of the rent-seeking behavior that occurs in Indonesia. As mentioned before, regional election is notorious to be associated with corruption practice, money politics, and nepotism between candidates and voters (Mietzner, 2010). This research will use 3 election time frames; the elections year, a year prior to the elections, and two years prior to the election. The election time frames is selected to observe when and how far the head of regional governments are starting to exploit resources and regional budget for the sake of their group or personal gain.

\section{RESEARCH METHODS}

The samples used in this research are all regionals or cities government in Indonesia by considering data availability related to the state budget (APBN) and the report on audit result conducted by Financial Audit Board (BPK) towards the financial report of regional/ city in Indonesia. Data are obtained from BPK, Central Bureau of Statistics (BPS), and The General Directorate of Regional Autonomy. 
The research will also disaggregate the administrative expenses to identify the discretionary and nondiscretionary components. Allegedly, some incumbents of regional government are suspected increasing discretionary fund during the period close to the time of elections. This fund is allegedly to be distributed to social, religious and sports community to gain more popularity. In several cases, they took the opportunity to fund their campaign activities. In this case, discretionary fund will be usually included and listed as "social relief fund" under the administrative expenditure items with subcategories "miscellaneous expenses". Below is the model to test the hypotheses of this research

$$
\begin{array}{r}
\text { Expenditure }_{i, t}=\alpha_{0}+\alpha_{1} \text { SIZE }_{i, t}+\alpha_{2} \text { Election }_{i, t}+\alpha_{3}{\text { Election } 1_{i, t}+\alpha_{4} \text { Election }_{i, t}+\alpha_{5} \text { Incumbent }_{i, t}+}+ \\
\alpha_{6} \text { Election }^{*} \text { Incumbent }_{i, t}+\alpha_{6} \text { Election }^{*} \text { Incumbent }_{i, t} \alpha_{6} \text { Election }^{*} \text { Incumbent } 2_{i, t}+\varepsilon
\end{array}
$$

We also include dummy for java and city to control the disparities in human and financial resources. District in Java or city usually have more financial resources and higher human development index than district in non-java or non-city.

\section{RESULT AND DISCUSSION}

We collect the financial information of APBD from the audit report of BPK (Audit Supreme Agency) from 2008 to 20013. Descriptive statistics is presented in Table 1.

Table 1: Descriptive Statistic

\begin{tabular}{cccccc}
\hline \hline & $\mathbf{N}$ & Mean & Std. Deviation & Minimum & Maximum \\
\hline Town & 2949 & 0.1905 & 0.3928 & 0 & 1 \\
Java & 2943 & 0.2286 & 0.42 & 0 & 1 \\
Incumbent & 898 & 0.5879 & 0.4924 & 0 & 1 \\
SIZE & 2798 & 27.24 & 0.547 & 22.42 & 29.44 \\
GANEX & 2796 & 27.22 & 0.5516 & 22.21 & 30.8 \\
SOCEX & 1837 & 22.8 & 1.412 & 14.5 & 30.8 \\
Grant & 1795 & 23.17 & 1.252 & 15.37 & 26.97 \\
\hline \hline
\end{tabular}

Notes: SOCEX and GANEX are natural logarithm of Social expenditure and grant expenditure respectively. Dummy election (one for the year of election and zero otherwise); dummy election1 (one for the year prior to the election and zero otherwise); dummy election 2 (one for the two years prior to the election and zero otherwise); dummy incumbent (one if the incumbent running for reelection and zero otherwise). Size is natural logarithm of distric/city income.

Between 2008 and 2013, 492 districts have been obtained from the district/city government with 2,949 total observations. The table shows that incumbent variable has a median of 0.5879 which indicates that almost $60 \%$ of district head is re-nominated in the following election. This research uses the proxy of social assistance expenditure and grant expenditure to measure rent-seeking behavior. These items are selected to be the proxy of rent seeking behavior because, in many cases, these two expenditures have been indicated to be abused by the regional governments.

The time span used to observe the PBC is 3 (three) years - which is year of election, 1 year prior to the election and 2 years prior to the election. To examine the rent-seeking behavior of budget allocation, we create interaction variables between the elections period and the status of the head district (incumbent or non-incumbent). The result of hypothesis test to see the impact of incumbent and interaction with the election is presented in the Table 2. 
Table 2: Rent-seeking and political budget cycle

\begin{tabular}{|c|c|c|c|c|c|c|}
\hline \multirow{2}{*}{ Variables } & \multicolumn{2}{|c|}{ Social expenditure } & \multicolumn{2}{|c|}{ Grant expenditure } & \multicolumn{2}{|c|}{ Grant+Soc } \\
\hline & 1 & 2 & 3 & 4 & 5 & 6 \\
\hline \multirow[t]{2}{*}{ Constant } & $0.009 * *$ & $-7.219 * * *$ & $-9.143 * * *$ & $-14.077 * * *$ & $-5.675^{* * *}$ & -11.615 \\
\hline & (1.618) & $(2.534)$ & (1.300) & (2.183) & $(0.912)$ & (1.397) \\
\hline \multirow[t]{2}{*}{ Size } & $0.834 * * *$ & $1.081 * * *$ & $1.181 * * *$ & $1.361 * * *$ & $1.084 * * *$ & $1.293 * * *$ \\
\hline & $(.059)$ & $(0.092)$ & $(0.047)$ & $(0.079)$ & $(0.033)$ & $(0.050)$ \\
\hline \multirow[t]{2}{*}{ Election } & -0.014 & $1.700 * * *$ & $0.541 * * *$ & $-0.968 * *$ & $0.239 * * *$ & $0.576^{*}$ \\
\hline & $(0.092)$ & $(0.577)$ & $(0.073)$ & $(0.492)$ & $(0.052)$ & $(0.318)$ \\
\hline \multirow[t]{2}{*}{ Election1 } & 0.049 & -0.290 & $0.390 * * *$ & 0.913 & $0.200 * * *$ & 0.572 \\
\hline & $(0.084)$ & $(0.906)$ & $(0.067)$ & $(0.773)$ & $(0.047)$ & $(0.500)$ \\
\hline \multirow[t]{2}{*}{ Election2 } & $0.382 * * *$ & -0.916 & 0.012 & 0.309 & $0.138 * * *$ & -0.137 \\
\hline & $(0.086)$ & (1.279) & $(0.070)$ & (1.091) & $(0.048)$ & $(0.706)$ \\
\hline \multirow{2}{*}{ Incumbent } & & $1.457 * * *$ & & -0.043 & & $0.761 * * *$ \\
\hline & & $(0.189)$ & & $(0.167)$ & & $(0.104)$ \\
\hline \multirow{2}{*}{ Elect x Incumbent } & & $-2.555 * * *$ & & $1.662 * * *$ & & $-0.763 * *$ \\
\hline & & $(0.616)$ & & $(1.662)$ & & $(0.340)$ \\
\hline \multirow[t]{2}{*}{ Elect1 x Incumbent } & & -0.212 & & -0.246 & & -0.606 \\
\hline & & $(0.931)$ & & $(0.795)$ & & $(0.514)$ \\
\hline \multirow[t]{2}{*}{ Elect $2 \mathrm{x}$ Incumbent } & & 0.471 & & -0.250 & & -0.118 \\
\hline & & (1.297) & & (1.107) & & $(0.716)$ \\
\hline Java dummies & Yes & Yes & Yes & Yes & Yes & Yes \\
\hline City dummies & Yes & Yes & Yes & Yes & Yes & Yes \\
\hline Method & OLS & OLS & OLS & OLS & OLS & OLS \\
\hline Observations & 1811 & 568 & 1770 & 557 & 1834 & 574 \\
\hline R-squared & 0.1043 & 0.2608 & 0.2819 & 0.3729 & 0.3701 & 0.547 \\
\hline
\end{tabular}

Note: This table reports pooled OLS regression. The dependent variable are social expenditure, grant expenditure, and the total of social and grant expenditures. Independent variables are dummy election (one for the year of election and zero otherwise); dummy election1 (one for the year prior to the election and zero otherwise); dummy election2 (one for the two years prior to the election and zero otherwise); dummy incumbent (one if the incumbent running for re-election and zero otherwise). Size is natural logarithm of regional income. $* * *, * *, *$ denote significance at the 1,5 , and $10 \%$ level.

There are 6 (six) models to examine the effect of elections time/period and the status of district head toward rent-seeking behavior. During 2 years prior to the election, there is a significant increase in social assistance expenditure and grant expenditure. It shows that there might be a misappropriation of budgetary fund and regional government revenue for the benefit of personal and groups.

The result also shows that there is a different strategy of budget allocation within the observation period. Within the period of 2 years before the election, the regional government heads will prefer to raise the expenditure of their social assistance. This strategy is used to create an impression that they are close and attentive to the community (voters) by distributing social assistance fund to the people. However, within the period of 1 year before the election, there is a significant increase in grant expenditures. This mechanism or strategy might be the easiest way for the regional government to get campaign resources for the following elections.

The 2nd and 6th model shows that the incumbents have a positive and significant effect toward the amount of social assistance expenditure and grant expenditure. It also shows that there might be rentseeking behavior within incumbents, who rerun for the following elections. 
The 4th model presents differential effect by testing the interaction between the incumbents status toward elections period. From the model, it is shown that the regional where the incumbent is going to be re-nominated has high grant expenditures. These grant expenditures within elections period will spend 150 percent larger than the non-incumbent district. On average, the models provided in Table 2 have low R-squared. This might be the case that we do not control some other important variables that might be significantly affect social and grant expenditure.

This research examines the behavior of regional governments' expenditure by using disaggregation of district expenditure. Government expenditures considered vulnerable to be abused are grant and social assistance expenditures. This research also tests the amount of such expenditures although it is not significant. As expected, regional governments tend to spend discretionary budget that will probably use for group or personal interests.

\section{CONCLUSION}

This study provide evidence on the political budget cycle during the period of election and it exists in almost in all regional government. This pattern could be used as an identification of rent-seeking behavior in regional governments. The rent-seeking behavior becomes extensive when incumbents run for the next elections. Regional governments prefer to choose the discretionary expenditure component which can be utilized for their group or personal benefit. They who are not running for the next elections tend to have small incentive to utilize the government budget except if they have political interest with the candidate of the following period.

The high cost of politics might be the main factor why political cartels do practice of rent-seeking within the resource owned by the regional government to maintain their power. Political party laws only regulate the contributions to political parties but does not regulate toward other campaign operation funding source. Direct election might give a broad opportunity to the government officials, who come from political parties, to distribute social assistance fund originating from state budget on the behalf of the state officials.

Based on the conclusions above, there are two recommendations to eradicate the practice or rent-seeking behavior in regional governments; minimizing asymmetric information and budget discretion. Asymmetric information could be reduced by giving a transparent access to the budget and its realization to community or to related stakeholders, so they can review and control the allocation of government resources.

Budget discretion factor could be minimized by implementing some policies, such as blocking the chance of rent-seeking indication toward APBD by giving a long vacation to the incumbent - who wants to run re-election and establishing a moratorium or restriction in grants program and social assistance.

\section{ACKNOWLEDGEMENT}

We would like to thank the participants at the 3rd Sebelas Maret International Conference on Business, Economics and Social Sciences, 3rd-4th August 2016 in Solo, Indonesia for valuable comments, and Huseina Wardana and Fahriza Luthfiandi for their excellent research assistant. We also grateful to Universitas Sebelas Maret for providing funding through the Fundamental Research Grant scheme. 


\section{REFERENCES}

Abdullah, S., \& Asmara, J. A. (2006). Perilaku Oportunistik Legislatif Dalam Penganggaran Daerah Bukti Empiris Atas Aplikasi Agency Theory Di Sektor Publik. Paper presented at Simposium Nasional Akuntansi, Padang, Indonesia.

Arifin, T., Trinugroho, I., Prabowo, M. A., Sutaryo S., \& Muhtar, M. (2015). Local governance and corruption: Evidence from Indonesia. Corporate Ownership and Control, 12(4), 194-199.

Banfield, E. C. (1975). Corruption as a Feature of Government Organization. The Journal of Law and Economics, 18(3), 587-605.

Becker, G. S., \& Stigler, J. (1974). Law Enforcement, Malfeasance, and the Compensation of Enforcers. Journal of Legal Studies, 3(1), 1-18.

Brender, A. (2003). The effect of fiscal performance on regional government election results in Israel: 1989-1998. Journal of Public Economics, 87(9-10), 2187-2205.

Brender, A., \& Drazen, A. (2005). Political budget cycles in new versus established democracies. Journal of Monetary Economics, 52(7), 1271-1295.

Farhan, Y. (2013). Menelusuri Siklus Politisasi Anggaran pada Tahun Pemilu. Jurnal Pemilu dan Demokrasi, 5, 29-48.

Klitgaard, R. (1988). Controlling Corruption. Barkeley, CA: University of California Press.

Krueger, A. O. (1974). The Political Economy of the Rent Seeking Society. American Economic Review, 64(3), 291-303.

Martinez-Vazquez, J., Arze, F. J., \& Boex, J. (2006). Corruption, Fiscal Policy, and Fiscal Management. USA: Georgian State University-USAID.

Mauro, P. (1998). Corruption and the Composition of Government Expenditure. Journal of Public Economics, 69, 263-279

Mietzner, M. (2011). Funding Pilkada: Illegal campaign financing in Indonesia's regional elections. In E. Aspinall \& G. van Klinken (Eds.), The State and Illegality in Indonesia (pp. 123-138). Leiden: KITLV Press.

Mietzner, M., 2010. Indonesia's direct elections: empowering the electorate or entrenching the new order oligarchy? In E. Aspinall \& G. Fealy (Eds.), Soeharto's New Order and its Legacy (pp. 173190). Canberra: ANU E Press.

Rose-Ackerman, S. (1975). The Economics of Corruption. Journal of Public Economics, 4(2), 187-203

Rose-Ackerman, S. (1978). Curruption: A Study of Political Economy. New York: Academic Press.

Shi, M., \& Svensson, J. (2006). Political budget cycles: do they differ across countries and why? Journal of Public Economics, 90(8-9), 1367-1389

Shleifer, A., \& Vishny, R. W. (1994). Politicians and firms. Quarterly Journal of Economics, 109(4), 995-1025

Shleifer, A., \& Vishny, R. W. (1998). The grabbing hand: government pathologies and their cures. Cambridge, Massachusetts: Harvard University Press.

Simandjuntak, D. (2012). Gifts and promises: patronage democracy in a decentralised Indonesia. European Journal of the East Asian Studies, 11(1), 99-128.

Sjahrir, B. S., Kis-Katos, K., \& Schulze, G. G. (2013). Political budget cycles in Indonesia at district level. Economics Letter, 120(2), 342-345.

Tanzi, V., \& Davoodi, H. (1997). Corruption, Public Investment, and Growth. IMF Working Paper WP/97/139.

Valsecchi, M. (2013). Local Elections and Corruption during Democratization: Evidence from Indonesia (Unpublished doctoral dissertation). University of Gothenburg, Sweden. 